\title{
AN EXPLORATORY STUDY OF EFFICACY OF COMMON BUSINESS CRITICAL THINKING COURSE: DO CIS MAJORS PERFORM BETTER THAN OTHER BUSINESS MAJORS?
}

\author{
Kazuo Nakatani, Florida Gulf Coast University, knakatan@fgcu.edu \\ Judy Wynekoop, Florida Gulf Coast University, jwynekoo@fgcu.edu
}

\begin{abstract}
This study describes an exploratory investigation of the effectiveness of a common business course designed to improve sophomore and junior business students' critical thinking skills using the case study method. The focus was on identifying how the CIS major students perform in the course. The impact of student academic intrinsic motivation on critical thinking skill acquisition was studied, as previous studies have shown persistence and effort are required. The results indicate that the course was effective, the control aspect of the intrinsic motivation may have positive correlation with the critical thinking acquisition, and CIS majors perform well in the critical thinking skill acquisition.
\end{abstract}

Keywords: Critical Thinking, Intrinsic Motivation, Course Effectiveness, Learning Outcome Assessment

\section{INTRODUCTION}

Critical thinking (CT) skills are among the most important soft skills employers want from college graduates (Jones, Leonard, \& Lang, 2018; Wall Street Journal, 2010). Critical thinking is necessary to deal with the exponentially increasing volume of information at our fingertips (Halpern, 1998). Accrediting bodies, employers and business colleges emphasize the importance of the ability for business majors to be able to think critically. The IS 2010 Information Systems Curriculum Guidelines (Topi, et al., 2010) emphasize that critical thinking skills are fundamental to the work of an information systems (IS) professional.

Critical thinking, often referred to as higher-order thinking, can be learned (Halpern, 1998). However, persistence and effort is required to develop higher-order thinking skills, as well as apply them (Halpern, 1998). Therefore, individuals with greater motivation may be considered to learn and apply critical thinking skills better than those with lower motivation. Also, different majors have been shown to perform differently in an objective critical thinking assessment test (Brown and Bielinska-Kwapisz, 2015); however, CIS majors were not included in that study. Thus, this study investigates (1) the relationship of intrinsic motivation to the effectiveness of a common course for business majors designed to improve critical thinking skills, and (2) the effects of the course on different majors, especially CIS majors.

This report first reviews critical thinking followed by a discussion of intrinsic motivation in an academic context. Then, the critical thinking for business course developed for business sophomore and junior students. Next, the methodology of this exploratory investigation is elaborated. Finally, the results of the investigation are discussed.

\section{LITERATURE REVIEW}

\section{Critical Thinking}

There are numerous definitions of critical thinking. Critical thinkers are open minded, able to interpret and analyze information in a variety of settings, evaluate the credibility of information, infer the consequences of a decision, and justify and communicate their reasoning effectively (Halpern, 1998). In business education research, critical thinking skills have been generally defined as the ability to evaluate sources of information, challenge assumptions, understand context, analyze arguments, and use metacognition (Brown and Bielinska-Kwapisz, 2015). The following aspects of critical thinking was emphasized in this study and the critical thinking course developed, based on the preceding: the ability to examine a business problem or situation from multiple perspectives; identify, evaluate, and apply relevant 


\section{Issues in Information Systems}

Volume 20, Issue 2, pp. 18-28, 2019

information and evidence; make a decision or develop a solution; and effectively communicate the solution and its justification.

\section{Critical Thinking in the Business Curriculum}

Business school graduates, including CIS majors, should be able to think effectively in organizational contexts. Much has been written on how to teach problem solving and critical thinking skills in business curricula. Yet, few business curricula include a course dedicated to critical thinking (Smith, 2014; Bandyopadhyay \& Szostek, 2019). Such a course offers a place where assessment "loop closing" can occur - that is, when students are found to be deficient in critical thinking, or analysis skills, there is a single course where changes can be made to improve outcomes. Without such a course, debates occur as to where in the curriculum such skills should be taught, and they rarely find a home (Smith, 2014).

A study that used the Collegiate Learning Assessment (CLA) to measure critical thinking skills shows that college students only minimally improve critical thinking skills and business students, among all the majors assessed, improves the smallest amount during the first two years of college (Arum \& Roksa, 2011). Yet, a newer study shows that business students exhibited improvement in some critical thinking assignments while decline in other critical thinking assignments measured at two different times (Bandyopadhyay \& Szostek, 2019).

Some interventions and assessments for critical thinking include writing skills, since in order to present an analysis one must write well. For example, AACSB-International, an accrediting body for business schools, includes the following in the undergraduate business curriculum coverage: students should be able to demonstrate "higher-order cognitive skills to analyze an unstructured problem, formulate and develop a solution using appropriate technology, and effectively communicate the results to stakeholders" (AACSB, 2018, p. 35). Success at critical thinking and writing are intertwined (Bailey, Zanchetta, Velasco, \& Pon, 2015). For example, writing and critical thinking were the focus of a multi-disciplinary intervention in large undergraduate classes (Bernstein \& Greenhoot, 2014). AAC\&U Value Rubrics were used to assess critical thinking and writing ability. Scores showed that students in the enhanced courses performed better in critical thinking and writing than did students in equivalent courses without the intervention. Additionally, improvements lasted over time (Bernstein \& Greenhoot, 2014).

Others examine the total effect of business education on critical thinking (Brown \& Bielinska-Kwapisz, 2015). Brown and Bielinska-Kwapisz (2015) administered the California Critical Thinking Skills Test (CCTST) to graduating seniors in the business college and found that total critical thinking scores differed by majors, with accounting majors having the highest critical thinking scores, followed by finance, marketing and management. In their study, CIS or information systems-oriented majors were not included. They also found that ACT scores (a proxy for innate cognitive ability) and GPA (a proxy for effort) were related to total critical thinking scores, as well as scores on some individual subscales. Since most of the variation in total critical thinking scores of students with high critical thinking scores was explained by GPA but not ACT scores, the authors conclude that the academic curriculum influences critical thinking scores and that students with high critical thinking scores benefitted the most from the curriculum, as the higher scores were due to something other than innate ability as measured by ACT scores (Brown \& Bielinska-Kwapisz, 2015). However, some have questioned whether the business curriculum improves critical thinking or filters out students without the higher order thinking skills (Coleman, Mason, \& Steagall, 2012).

There remains uncertainty about how to assess critical thinking in specific disciplines in higher education (Bandyopadhyay \& Szostek, 2019). Research has indicated critical thinking may be best assessed using multiple methods in multiple settings (Halpern, 1998). Instruments that have been used include the CCTST and CLA, as noted above, as well as the Watson-Glaser a Thinking Appraisal (Watson \& Glaser, 1964) and the HEIghten Critical Thinking Assessment (https://www.ets.org). These assessments all measure some of the various dimensions of critical thinking, such as deductive and inductive reasoning, reasoning and evaluation ability, and interpretation and inference skills. Other studies have used student self-assessment (Davis, Thomas, \& Kazlaukas, 2006), instructor assessment (Pomykalski, 2006; Wang \& Wang, 2011), and instructor use of AAC\&U Value Rubrics (Bernstein \& Greenhoot, 2014). In this exploratory study, a rubric developed for the university-wide Quality Enhancement Program based on the AAC\&U Critical Thinking Value Rubric is used (Asociation of American Colleges and Universities, 2009). 


\section{Issues in Information Systems}

Volume 20, Issue 2, pp. 18-28, 2019

\section{Intrinsic Motivation}

The development of critical thinking requires hard work and time. Paul and Elder (2001) wrote "no intellectual pain, no intellectual gain" as analogy to physical conditioning famous phrase of "no pain, no gain", since critical thinking develops in stages, over time. They emphasized the importance of willingness to practice more than ordinary effort even when uncomfortable, challenging and difficult, and that critical thinking must be nurtured. While routine problems can be easily solved, critical thinking when people face the challenge of developing skills that are not naturally interesting, they are not intrinsically motivated; therefore, developing or possessing the willingness to do such activities would be valuable (Deci, Eghrari, Patrick, \& Leone, 1994). Some students show persistence in learning while others do not and motivation may play a very important role. French and Oakes (2003) note that several studies show correlations between higher levels of motivation and continued work on a task even when people face difficulties on the task.

Academic motivation can be extrinsic and intrinsic. Academic extrinsic motivation is defined as learning and involvement in academic tasks to satisfy others' expectations and academic intrinsic motivation is defined as selfmotivation and enjoyment of academic learning and tasks (Richardson, Abraham, \& Bond, 2012). Intrinsic motivation is classified as autonomous motivation and considered high-quality motivation, while extrinsic motivation needs to be internalized to be autonomous motivation; otherwise external motivation is classified as controlled motivation and considered low-quality motivation (Deci \& Ryan, 2008).

Two examples of instruments that measure motivation are the Motivation Strategies for Learning Questionnaire (MLSQ), which measures both extrinsic and intrinsic motivation (Pintrich \& DdeGroot, 1990) and the Intrinsic Motivation Inventory (IMI) originated by Ryan (1982) which measures participant's subjective experience related to a target activity in laboratory experiments. The MLSQ uses only four questions to measure intrinsic motivation. The construct validity of IMI has not yet been confirmed (Markland \& Hardy, 2013). The Academic Motivation Scale (AMS) is the English version of the Echelle de Motivation Education (EME) originally developed in the French (Vallerand \& Bissonnette, 1992). It uses 28 items to assess three types of intrinsic motivation, three types of extrinsic motivation, and amotivation (Vallerand, et. al., 1992).

A study by French and Oakes (2003) reviewed the MSLQ, AMS and several other instruments to measure academic motivation and developed an instrument (the Academic Intrinsic Motivation Scale, AIMS) applicable to first year college students based on them. French and Oakes (2003) postulated that the academic intrinsic motivation of college students may depend on their perceptions of the level of challenge of their courses, their perceived control over academics, their academic curiosity, and their anticipation of successful graduation and employment. Their 25-item instrument measures perceived challenge, control, curiosity and career outlook. Overall intrinsic motivation as measured on the AIMS was related to persistence in the major among engineering students (French, Immekeus, \& Oakes, 2005). The AIMS (French \& Oakes, 2013) is used in this study.

\section{CRITICAL THINKING FOR BUSINESS AS COMMON BUSINESS COURSE}

A critical thinking for business course was developed to respond to the assurance of learning assessment (AOL) results at a business college at a Southwest Florida university. The college and the university-wide Quality Enhancement Program team had assessed critical thinking skills of graduating seniors using a writing assignment that involves critical thinking and writing for several years. The results consistently showed poor performance. The college faculty formed a subcommittee in 2017 to develop a critical thinking for business course targeting sophomore and junior students.

The course primarily targeted sophomore students for two reasons. First, skill acquisition, especially critical thinking skills, requires hard work and takes time (Paul and Elder, 2001). Therefore, it is important to expose the concept of critical thinking early in the undergraduate curriculum to allow sufficient time to develop the skills. Second, the course was intended to prepare students for upper division courses in their major. The course encourages students to understand the importance of numeracy, analysis, effective use of evidence and multi-functional and long-term vs short-term perspectives to benefit students in their upper-division courses. The course emphasized the following aspects of critical thinking: 
1. Evidence-based reasoning

2. Application of sound logic

3. Consideration of multiple perspectives

4. Reasonable validity of assumptions

5. Interpretation and synthesis of evidence and quantitative data

The course was first offered as a special topics course in Spring 2018 and was available as a choice in the business core (either this course or Professional Writing taught by College of Arts and Sciences) in Fall 2018. The course utilizes the case study method to enhance the critical thinking skills, requiring students to write case reports and receive individual feedback about their writing and critical thinking on drafts. To provide individual feedback to each student, each section of the course was capped at 25 . Students wrote six business reports in the class. They received feedback on 4 of the drafts and could resubmit them for a final grade. However, for the remaining two case reports written during the in-class midterm and final exams, no drafts were submitted and no feedback were given in order to assess the student's learning outcome of critical thinking more accurately.

\section{METHODOLOGY}

Sixty-two students in three sections of the course completed the AIMS (French and Oakes, 2003) instrument with a 5-point scale, where 5 represents "strongly agree" and 1 represents "strongly disagree" near the end of Fall 2018, resulting in an academic intrinsic motivation score measured in four aspects as shown in Figure 1. Fifty-three of these results were usable. The same survey asked students to report their major. These independent variables were then used to investigate their impacts on students' critical thinking assessment scores.

As an exploratory study, several dependent variables were studied. First, the midterm case report score and the final exam report score, which included not only critical thinking but also writing and information literacy (measured with a 5 point-scale using a rubric based on AAC\&U Value Rubrics) were investigated. The study also investigated only the critical thinking aspect of the reports using only two criteria of the rubric (Content Development and Evaluation of Information). Also, midterm case report scores, indicating a starting level of critical thinking, were subtracted from final paper scores, to yield an improvement score.

Several statistical methods were applied to investigate the relationship between the independent variables and the dependent variables. Those include a paired samples t-test and partial least squares regression (PLS). A paired samples t-test was selected to test improvement between the midterm exam and final exam scores. PLS was selected to test the model shown in Figure 1 since PLS is suitable for investigating a construct, such as internal motivation, that requires latent variables to be modeled, PLS does not required a large sample size, PLS does not require normally-distributed input data, and PLS is appropriate for theory development (Urback \& Ahlemann, 2010).

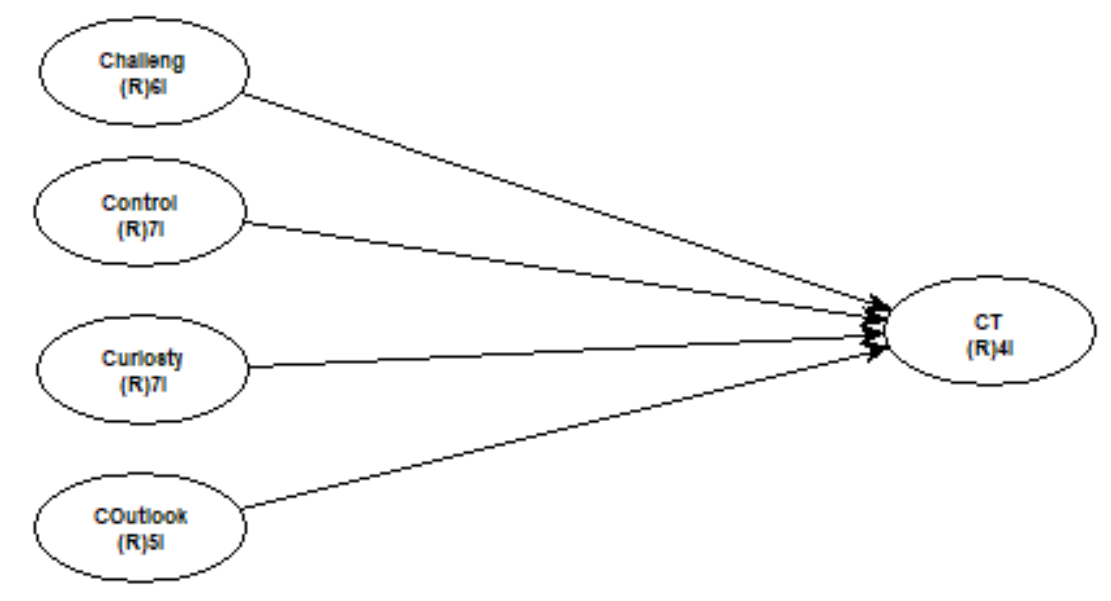

Figure 1. Conceptual Model of Effect of Intrinsic Motivation on Critical Thinking 


\section{Propositions Investigated}

Several propositions were developed for this exploratory pilot study. First, based on the work of Halpern (1998) and Bernstein and Greenhoot (2014), the critical thinking course is expected to improve students' critical thinking ability. We propose:

P1: Course intervention in critical thinking will be related to improved critical thinking ability.

French and Oakes (2003) based the development of their instrument of studies using intrinsic motivation to model student success. As the acquisition of critical thinking skills may require persistence and continuous effort, intrinsic motivation may play an important role in the skill acquisition. Thus, as shown above in Figure 1, we propose:

P2: Critical thinking ability is positively related to intrinsic motivation.

Based on the findings of Brown and Bielinska-Kwapisz (2015) that critical thinking ability differs across majors and the business curriculum improves critical thinking, we propose:

P3a: Critical thinking scores will differ across majors.

P3b: Improvement in critical thinking will differ across majors.

Finally, since we have proposed that course grade and intrinsic motivation will be related to improvement in critical thinking and that critical thinking improvement will differ across majors, we also propose that:

P4: Course grades will differ across majors.

P5: Levels of intrinsic motivation will differ across majors.

\section{RESULTS}

Proposition 1 was investigated using the midterm exam score and final exam score with a paired samples t-test. Students performed significantly better on the final case (mean score $82.8 \%$ ) than on the midterm case (mean score $78.9 \%) ; \mathrm{t}=-2.9, \mathrm{p}<.01$. Thus, it is possible that the course improved student's critical thinking skills that also include writing and information literacy aspects.

Table 1. Exam Score Means

\begin{tabular}{|c|c|c|c|c|}
\hline & Mean & $\mathrm{N}$ & Std. Deviation & Std. Error Mean \\
\hline Midterm & $78.9 \%$ & 53 & $10.4 \%$ & $1.4 \%$ \\
\hline Final & $82.8 \%$ & 53 & $11.6 \%$ & $1.6 \%$ \\
\hline
\end{tabular}

Proposition 2 using the conceptual model presented before was investigated using PLS. The result in Figure 2 shows only the "control" aspect of the intrinsic motivation was significantly positively correlated to the critical thinking skill measured in the two aspects (content development and evaluation of information) at $p<0.01$. Unexpectedly, challenge, curiosity and career outlook do not show significant correlation with the critical thinking skill. Interestingly, curiosity showed negative correlation with the critical thinking skill although it is not significant. Additionally, the overall model $\left(\mathrm{R}^{2}\right)$ was not significant. 


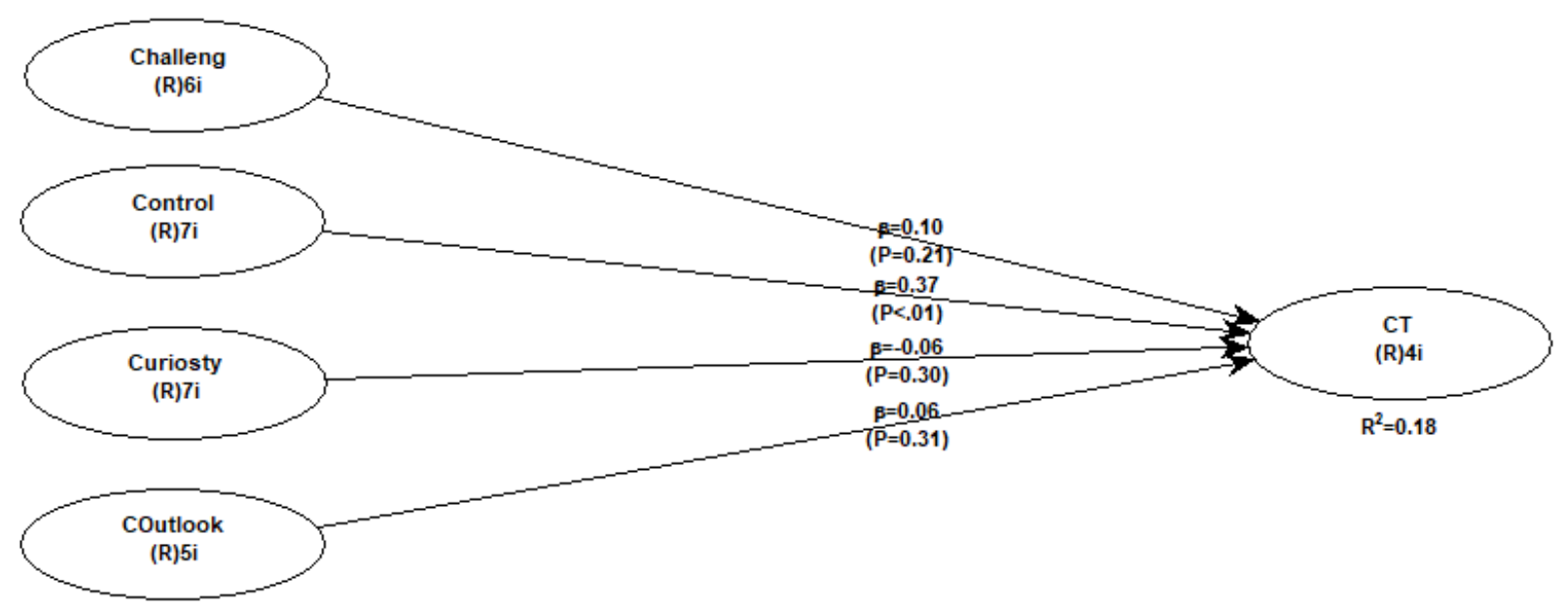

Figure 2. PLS Results of Intrinsic Motivation and Critical Thinking Skill

Table 2 shows the summary of grades and critical thinking scores for different majors and Table 3 shows the summary of intrinsic motivation scores for different majors. As there was no control over who could enroll in the course, there were only few students in certain majors including the CIS major. Therefore, statistical analysis was not conducted to test propositions 3 through 5 .

Table 2. Descriptive Statistics of Course Grades, Average Critical Thinking Scores and Improvement

\begin{tabular}{|c|c|c|c|c|c|c|c|c|}
\hline & & \multicolumn{2}{|c|}{$\begin{array}{c}\text { Avg. } \\
\text { Course } \\
\text { Grade } \\
\text { Major }\end{array}$} & \multicolumn{2}{|c|}{$\begin{array}{c}\text { Avg. CT Score of } \\
\text { Midterm (Rank) }\end{array}$} & \multicolumn{2}{|c|}{$\begin{array}{c}\text { Avg. CT Score of } \\
\text { Final Exam (Rank) }\end{array}$} & \multicolumn{2}{|c|}{$\begin{array}{c}\text { Improvement in Avg. } \\
\text { CT Score }\end{array}$} \\
\hline & $\mathrm{n}$ & & Content $^{1}$ & Evaluation $^{2}$ & Content & Evaluation & Content & Evaluation \\
\hline Accounting & 9 & $81.6(5)$ & $2.22(7)$ & $3.00(7)$ & $3.44(4)$ & $3.33(4)$ & 1.22 & 0.33 \\
\hline CIS & 4 & $86.6(3)$ & $3.75(2)$ & $4.75(1)$ & $4.25(1)$ & $3.75(3)$ & 0.50 & -1.00 \\
\hline Economics & 2 & $80.1(6)$ & $4.00(1)$ & $4.00(3)$ & $2.50(6)$ & $3.00(6)$ & -1.50 & -1.00 \\
\hline Entrepreneurship & 3 & $79.9(7)$ & $3.33(5)$ & $3.33(6)$ & $2.00(7)$ & $2.67(7)$ & -1.33 & -0.66 \\
\hline Finance & 11 & $89.1(1)$ & $3.55(4)$ & $4.09(2)$ & $4.18(2)$ & $4.09(1)$ & 0.63 & 0.00 \\
\hline Management & 16 & $86.7(2)$ & $3.56(3)$ & $4.00(3)$ & $4.06(3)$ & $3.94(2)$ & 0.50 & -0.06 \\
\hline Marketing & 8 & $83.2(4)$ & $2.88(6)$ & $3.63(5)$ & $3.13(5)$ & $3.25(5)$ & 0.25 & -0.38 \\
\hline Total & 53 & 85.2 & 3.25 & 3.81 & 3.68 & 3.64 & 0.43 & -0.17 \\
\hline
\end{tabular}

Note: The numbers in parentheses are ranking among the majors.

${ }^{1}$ Content Development criteria on the rubric

${ }^{2}$ Evaluation of Information criteria on the rubric

Accounting majors did not perform well, with the lowest average score in the critical thinking aspect on the midterm exam. However, they improved the most when their score was compared to the final exam. This conflicts with the findings of Brown and Bielinska-Kwapisz (2015). One interesting finding from conversation with an accounting major student was that he believed that he needed only analysis of financial data to make a decision. This single-factor analysis may not facilitate critical thinking, which requires analysis from multiple perspectives. He changed his view for the final exam once he recognized the single-factor analysis hurt his grade.

The CIS majors performed fairly well on the course grade, midterm exam and final exam although they showed a decline in the evaluation of information and conclusion from the midterm to the final exam. Yet, this decline was observed in many majors. The case difficulty could be attributed to the decline. The CIS majors showed the second highest scores in the content development aspect and the highest in the evaluation of information and conclusion aspect of critical thinking in the midterm. The CIS majors showed the highest scores in the content development aspect 
and the third highest in the evaluation of information and conclusion aspect of critical thinking in the final exam. The CIS majors consistently performed relatively well among the business majors.

Table 3. Descriptive Statistics of Four Aspects of Intrinsic Motivation

\begin{tabular}{|c|c|c|c|c|c|c|}
\hline Major & $\begin{array}{c}\text { \# of } \\
\text { Subjects }\end{array}$ & $\begin{array}{c}\text { Avg. Score of } \\
\text { Challenge }\end{array}$ & $\begin{array}{c}\text { Avg. Score of } \\
\text { Control }\end{array}$ & $\begin{array}{c}\text { Avg. Score of } \\
\text { Curiosity }\end{array}$ & $\begin{array}{c}\text { Avg. Score of } \\
\text { Career } \\
\text { Outlook }\end{array}$ & $\begin{array}{c}\text { Avg. Score of } \\
\text { Overall }\end{array}$ \\
\hline Accounting & 9 & 4.17 & 3.90 & 3.84 & 4.16 & 4.00 \\
\hline CIS & 4 & 4.50 & 4.29 & 3.71 & 4.50 & 4.22 \\
\hline Economics & 2 & 4.75 & 4.43 & 4.14 & 4.90 & 4.52 \\
\hline Entrepreneurship & 3 & 4.67 & 4.10 & 4.10 & 4.60 & 4.33 \\
\hline Finance & 11 & 4.70 & 4.27 & 3.94 & 4.51 & 4.33 \\
\hline Management & 16 & 4.35 & 4.09 & 3.70 & 4.23 & 4.08 \\
\hline Marketing & 8 & 4.44 & 4.05 & 3.38 & 4.55 & 4.06 \\
\hline Total & 53 & 4.45 & 4.12 & 3.76 & 4.41 & 4.16 \\
\hline
\end{tabular}

As shown in Table 3 above, most students considered themselves motivated students as the average scores show 4 or higher (out of 5) in three of the four aspects. The scores in curiosity were relatively lower than the other three aspects. The CIS major students were in the mid-range of three of the four measures of intrinsic motivation, but they were second highest in the control aspect. The accounting students showed the lowest score in the challenge, control, career outlook and overall. This may explain the lower performance in the critical thinking score but the number of subjects is too few to make any conclusion.

\section{SUMMARY AND LIMITATIONS}

This exploratory pilot study investigated the impact of a business critical thinking course designed for sophomore and junior students with case study method on the students' (especially the CIS majors) critical thinking skills. The focus was also on how the students' intrinsic motivation affects the acquisition of critical thinking skills as previous studies showed persistence and effort is required to develop higher-order thinking skills. Overall, the case study method used in the course shows the potential to improve the business students' critical thinking skills, which was measured in the quality of their case reports, not objective multiple-choice questions.

The CIS majors performed fairly well compared to other business majors. Contradicting Brown and BielinskaKwapisz's (2015) findings, the accounting majors did not perform well. The CIS, finance and management majors performed better compared to the other majors.

The relationship between academic intrinsic motivation and critical thinking was not clearly shown. Only the control aspect of the intrinsic motivation shows significant positive correlation. This may suggest that the control aspect of the intrinsic motivation may be more closely related to the persistence and effort required to acquire critical thinking. The accounting students had low scores in the intrinsic motivation and the lowest score in the midterm. This may indicate some possible relationship between intrinsic motivation and critical thinking skill acquisition. Further development of the conceptual model and investigation are necessary.

Since this was an exploratory study, the convenience sample was small, and some majors included only two or three students. The use of a single assessor, who worked as a feedback provider and grader, not the primary course instructor who was responsible for designing the course and teaching, may have affected the accuracy of the critical thinking skill measurement. Regarding the assessment of the intrinsic motivation, the AIMS instrument has not been widely used, so it is possible a different instrument would have yielded different results. Additionally, critical thinking ability was assessed using student work and a university-wide rubric developed based on the AAC\&U VALUE Critical Thinking rubric. Further study is planned using additional motivation measures and the HEIghten Critical Thinking Assessment (https://ets.org) to determine whether there is a positive relationship between intrinsic motivation and improved critical thinking. 


\section{REFERENCES}

AACSB. (2018). 2013 Eligibility Procedures and Accreditation Standards for Business Accreditation. Tampa: AACSB.

Asociation of American Colleges and Universities. (2009). Critical Thinking VALUE Rubric. Retrieved June 27, 2019, from https://www.aacu.org/value/rubrics/critical-thinking

Arum, R. \& Roksa, J. (2011). Academically adrift. Chicago, IL: University of Chicago Press.

Bailey, A., Zanchetta, M., Velasco, D., \& Pon, G. (2015). Building a scholar in writing (BSW): A model for developing students' critical writing skills. Nurse Education in Practice, 15, 524-529.

Bandyopadhyay, S., \& Szostek, J. (2019). Thinking critically about critical thinking: Assessing critical thinking of business students using multiple measures. Journal of Education for Business, 94(4), 259-270,

Bernstein, D., \& Greenhoot, A. F. (2014). Team-Designed Improvement of Writing and Critical Thinking in Large Undergraduate Classes. Teaching \& Learning Inquiry, 2(1), 39-61.

Brown, F. W., \& Bielinska-Kwapisz, A. (2015). Understanding the Nature and Determinants of Critical Thinking among Senior Business Undergraduate Students. Journal of Education for Business, 90, 359-368.

Coleman, B., Mason, P., \& Steagall, J. (2012). Does a business curriculum develop or filter critical thinking? American Journal of Business Educations, 5(4), 409-415.

Deci, E.L. and Ryan, R.M. (2008). Facilitating Optimal Motivation and Psychological Well Being Across Life's Domains. Canadian Psychology, 49(1), $14-23$.

Deci, E.L., Eghrari, H., Patrick, B., \& Leone, D. (1994). Facilitating internalization: The self-determination theory perspective. Journal of Personality, 62(1), 119-142.

Facione, P. (1990). Excutive Summary of The Delphi Report. Retrieved April 10, 2019, from http://stearnscenter.gmu.edu/wp-content/uploads/12-The-Delphi-Report-on-Critical-Thinking.pdf.

French, B., \& Oakes, W. (2003). Measuring Academic Intrinsic Motivation in the First Year of College: Reliability and Validity Evidence for a New Instrument. Journal of the First Year Experience, 15(2), 83-102.

French, B., Immekeus, J., \& Oakes, W. (2005). An examination of indicators of engineering students' success and persistence. Journal of Engineering Education, 94(4), 419-425.

Halpern, D. (1998). Teaching critical thinking for treansfer across domains. American Psychologist, 53(4), 449-455.

Jones, K., Leonard, L., \& Lang, G. (2018). Desired skills for entry level IS positions: Identification and assessment. Journal of Computer Information Systems, 58(3), 214-220.

Markland D. \& Hardy L. (1997). On the factorial and construct validity of the Intrinsic Motivation Inventory: conceptual and operational concerns. Research Quarterly for Exercise and Sport, 68(1), 20-32.

Paul, R., \& Elder, L. (2001). Critical thinking: tools for taking charge of your learning and your life. Saddle River: Prentice Hall. 
Pintrich, R., \& DeGroot, E. (1990). Motivational and self-regulated learning components of classroom academic performance. Journal of Educational Psychology, 82, 33-40.

Richardson, M., Abraham, C., \& Bond, R. (2012). Psychological Correlates of University Students' Academic Performance: A Systematic Review and Meta-Analysis. Psychological Bulletin, 138(2), 353-387.

Ryan, R. (1982). Control and information in the intrapersonal sphere: An extension of cognitive evaluation theory. Journal of Personality and Social Psychology, 43, 450-461.

Smith, G. F. (2014). Assessing Business Student Thinking Skills. Journal of Management Education, 38(3), 384-411.

Topi, H., Valacich, J. S., Wright, R. T., Kaiser, K. M., Nunamaker, J. J., Sipior, J. C., deVreede, G.J. (2010). Curriculum Guidelines for Undergraduate Degree Programs in Information Systems. Association for Computing Machinery and Association for Information Systems.

Vallerand, R., \& Bissonnette, R. (1992). Intrinsic, extrinsic, and amotivational styles as predictors of behavior: A prospective study. Journal of Personality, 60, 599-620.

Wall Street Journal. (2010, September 13). Schools' Rankings Calculated From 479 Recruiter Responses.

\section{APPENDIX}

Twenty-five questions from (French \& Oakes, Measuring Academic Intrinsic Motivation in the First Year of College: Reliability and Validity Evidence for a New Instrument, 2003) were used to measure intrinsic motivation.

Challenge:

I have academic goals.

I am confident I can complete degree.

I determine career goals.

I enjoy solving challenging difficult problems.

I work on an assignment until I understand it.

Control:

I am confident I will graduate from college.

I determine the quality of my academic work.

I am pursuing a college degree because I value education.

I feel good knowing that I determine how my academic career develops.

I have high standards for academic work.

Staying in college is my decision.

I study because I like to learn new things.

Curiosity:

I enjoy doing outside readings in connection to my course work.

I am intrigued by the different topics introduced in my courses.

I study because I am curious.

I look forward to going to class.

I am excited to take more courses within my major.

I enjoy learning more within my field of study.

I like to find answers to questions about material I am learning.

I enjoy studying.

Career outlook:

I have pictured myself in a profession after college.

I am excited about the job opportunities I will have when I graduate.

I have pictured myself being successful in my chosen profession. 


\section{Issues in Information Systems \\ Volume 20, Issue 2, pp. 18-28, 2019}

I believe I will make a substantial contribution to my chosen profession.

I feel good knowing I will be a member of the professional community in my area of study.

A rubric developed for the university-wide Quality Enhancement Program based on the AAC\&U Critical Thinking Value Rubric (Asociation of American Colleges and Universities, 2009) was used to measure writing, critical thinking, and information literacy.

\begin{tabular}{|c|c|c|c|c|c|}
\hline Critical Thinking & Level 4 & Level 3 & Level 2 & Level 1 & Level 0 \\
\hline $\begin{array}{l}\text { Content } \\
\text { Development }\end{array}$ & $\begin{array}{l}\text { Uses appropriate, } \\
\text { relevant, and } \\
\text { compelling content } \\
\text { to illustrate mastery } \\
\text { of the subject, critical } \\
\text { analysis and } \\
\text { synthesis skills that } \\
\text { convey the writer's } \\
\text { understanding. }\end{array}$ & $\begin{array}{l}\text { Uses appropriate, } \\
\text { relevant, and } \\
\text { compelling content } \\
\text { to explore ideas } \\
\text { using critical } \\
\text { thinking skills } \\
\text { within the context } \\
\text { of the discipline. }\end{array}$ & $\begin{array}{l}\text { Uses appropriate } \\
\text { and relevant } \\
\text { content to develop } \\
\text { and explore ideas } \\
\text { through most of the } \\
\text { work. }\end{array}$ & $\begin{array}{l}\text { Uses appropriate } \\
\text { and relevant content } \\
\text { to develop simple } \\
\text { ideas in some parts } \\
\text { of the work. }\end{array}$ & $\begin{array}{l}\text { Uses inappropriate } \\
\text { and irrelevant } \\
\text { content to develop } \\
\text { simple ideas in } \\
\text { many parts of the } \\
\text { work. }\end{array}$ \\
\hline $\begin{array}{l}\text { Evaluation of } \\
\text { Information: } \\
\text { Conclusion }\end{array}$ & $\begin{array}{l}\text { Skillfully analyzes } \\
\text { and evaluates } \\
\text { information / } \\
\text { evidence related to } \\
\text { thesis; conclusion is } \\
\text { insightful, logical } \\
\text { and justified based } \\
\text { on a skillful } \\
\text { evaluation of } \\
\text { evidence. }\end{array}$ & $\begin{array}{l}\text { Adequately } \\
\text { analyzes and } \\
\text { evaluates } \\
\text { information / } \\
\text { evidence related to } \\
\text { thesis; conclusion is } \\
\text { logical and justified } \\
\text { based on the } \\
\text { evaluation of } \\
\text { evidence. }\end{array}$ & $\begin{array}{l}\text { Attempts to analyze } \\
\text { and evaluate } \\
\text { information / } \\
\text { evidence related to } \\
\text { thesis and use the } \\
\text { evidence in order to } \\
\text { justify conclusions. }\end{array}$ & $\begin{array}{l}\text { Takes information } \\
\text { at face value (little } \\
\text { or no attempt to } \\
\text { evaluate quality of } \\
\text { information / } \\
\text { evidence, } \\
\text { relationship to } \\
\text { thesis, or support of } \\
\text { conclusions). }\end{array}$ & $\begin{array}{l}\text { Misinterpret } \\
\text { information (little } \\
\text { or no attempt to } \\
\text { evaluate quality of } \\
\text { information / } \\
\text { evidence, } \\
\text { relationship to } \\
\text { thesis, or support } \\
\text { of conclusions). }\end{array}$ \\
\hline Writing & Level 4 & Level 3 & Level 2 & Level 1 & Level 0 \\
\hline $\begin{array}{l}\text { Context of and } \\
\text { Purpose for } \\
\text { Writing [Includes } \\
\text { considerations of } \\
\text { audience, purpose, } \\
\text { and the } \\
\text { circumstances } \\
\text { surrounding the } \\
\text { writing task(s).] }\end{array}$ & $\begin{array}{l}\text { Demonstrates a } \\
\text { thorough } \\
\text { understanding of } \\
\text { context, audience, } \\
\text { and purpose that is } \\
\text { responsive to the } \\
\text { assigned tasks and } \\
\text { focuses all elements } \\
\text { of the work. }\end{array}$ & $\begin{array}{l}\text { Demonstrates } \\
\text { adequate } \\
\text { consideration of } \\
\text { context, audience, } \\
\text { and purpose and a } \\
\text { clear focus on the } \\
\text { assigned tasks (e.g., } \\
\text { the task aligns with } \\
\text { audience, purpose, } \\
\text { and context). }\end{array}$ & $\begin{array}{l}\text { Demonstrates } \\
\text { awareness of } \\
\text { context, audience, } \\
\text { purpose, and to the } \\
\text { assigned tasks (e.g., } \\
\text { begins to show } \\
\text { awareness of } \\
\text { audience's } \\
\text { perceptions and } \\
\text { assumptions). }\end{array}$ & $\begin{array}{l}\text { Demonstrates } \\
\text { minimal attention to } \\
\text { context, audience, } \\
\text { purpose, and to the } \\
\text { assigned tasks (e.g., } \\
\text { expectation of } \\
\text { instructor or self as } \\
\text { audience). }\end{array}$ & $\begin{array}{l}\text { Does NOT } \\
\text { demonstrate } \\
\text { attention to } \\
\text { context, audience, } \\
\text { purpose, and to } \\
\text { the assigned tasks. }\end{array}$ \\
\hline $\begin{array}{l}\text { Genre and } \\
\text { Disciplinary } \\
\text { Conventions } \\
\text { [Formal and } \\
\text { informal rules } \\
\text { inherent in the } \\
\text { expectations for } \\
\text { writing in } \\
\text { particular forms.] }\end{array}$ & $\begin{array}{l}\text { Demonstrates } \\
\text { detailed attention to } \\
\text { and successful } \\
\text { execution of a wide } \\
\text { range of conventions } \\
\text { particular to business } \\
\text { writing including } \\
\text { organization, content, } \\
\text { presentation, } \\
\text { formatting, and } \\
\text { stylistic choices. }\end{array}$ & $\begin{array}{l}\text { Demonstrates } \\
\text { consistent use of } \\
\text { important } \\
\text { conventions } \\
\text { particular to } \\
\text { business writing } \\
\text { including } \\
\text { organization, } \\
\text { content, } \\
\text { presentation, and } \\
\text { stylistic choices. }\end{array}$ & $\begin{array}{l}\text { Follows } \\
\text { expectations } \\
\text { appropriate to } \\
\text { business writing for } \\
\text { basic organization, } \\
\text { content, and } \\
\text { presentation. }\end{array}$ & $\begin{array}{l}\text { Attempts to use a } \\
\text { consistent business } \\
\text { writing system for } \\
\text { basic organization } \\
\text { and presentation. }\end{array}$ & $\begin{array}{l}\text { Does NOT } \\
\text { attempt to use a } \\
\text { consistent } \\
\text { business writing } \\
\text { system for basic } \\
\text { organization and } \\
\text { presentation. }\end{array}$ \\
\hline
\end{tabular}


Issues in Information Systems

Volume 20, Issue 2, pp. 18-28, 2019

\begin{tabular}{|c|c|c|c|c|c|}
\hline $\begin{array}{l}\text { Syntax and } \\
\text { Mechanics }\end{array}$ & $\begin{array}{l}\text { Uses eloquent } \\
\text { language that } \\
\text { skillfully } \\
\text { communicates } \\
\text { meaning to readers } \\
\text { with clarity and } \\
\text { fluency, and is } \\
\text { virtually error-free } \\
\text { (no spelling, } \\
\text { grammar and } \\
\text { punctuation errors). }\end{array}$ & $\begin{array}{l}\text { Uses } \\
\text { straightforward } \\
\text { language that } \\
\text { generally conveys } \\
\text { meaning to readers. } \\
\text { The language in the } \\
\text { portfolio has few } \\
\text { errors (only few } \\
\text { spelling, grammar } \\
\text { and punctuation } \\
\text { errors). }\end{array}$ & $\begin{array}{l}\text { Uses language that } \\
\text { generally conveys } \\
\text { meaning to readers } \\
\text { with clarity, } \\
\text { although writing } \\
\text { may include some } \\
\text { errors (some } \\
\text { spelling, grammar } \\
\text { and punctuation } \\
\text { errors). }\end{array}$ & $\begin{array}{l}\text { Uses language that } \\
\text { sometimes impedes } \\
\text { meaning because of } \\
\text { errors in usage (such } \\
\text { as spelling, } \\
\text { grammar and } \\
\text { punctuation). }\end{array}$ & $\begin{array}{l}\text { Uses language that } \\
\text { significantly } \\
\text { impedes meaning } \\
\text { because of errors } \\
\text { in usage (such as } \\
\text { spelling, grammar } \\
\text { and punctuation). }\end{array}$ \\
\hline Info. Literacy & Level 4 & Level 3 & Level 2 & Level 1 & Level 0 \\
\hline $\begin{array}{l}\text { Identification and } \\
\text { Access of } \\
\text { Information / } \\
\text { Evidence }\end{array}$ & $\begin{array}{l}\text { Demonstrates skillful } \\
\text { identification and } \\
\text { access of high- } \\
\text { quality, credible, } \\
\text { relevant sources to } \\
\text { develop ideas that are } \\
\text { appropriate for the } \\
\text { discipline and genre } \\
\text { of the writing. }\end{array}$ & $\begin{array}{l}\text { Demonstrates } \\
\text { consistent } \\
\text { identification and } \\
\text { access of credible, } \\
\text { relevant to support } \\
\text { ideas, that are } \\
\text { situated within the } \\
\text { discipline and genre } \\
\text { of the writing. }\end{array}$ & $\begin{array}{l}\text { Demonstrates an } \\
\text { attempt to identify } \\
\text { and access credible } \\
\text { and/or relevant } \\
\text { sources to support } \\
\text { ideas that are } \\
\text { appropriate for the } \\
\text { discipline and } \\
\text { genre of the } \\
\text { writing. }\end{array}$ & $\begin{array}{l}\text { Has difficulty } \\
\text { identifying and } \\
\text { accessing sources to } \\
\text { support ideas in the } \\
\text { writing. }\end{array}$ & $\begin{array}{l}\text { Does NOT } \\
\text { identify and } \\
\text { access sources to } \\
\text { support ideas in } \\
\text { the writing. }\end{array}$ \\
\hline $\begin{array}{l}\text { Use Information } \\
\text { Effectively to } \\
\text { Accomplish a } \\
\text { Specific Purpose }\end{array}$ & $\begin{array}{l}\text { Skillfully } \\
\text { communicates, } \\
\text { organizes and } \\
\text { synthesizes } \\
\text { information from } \\
\text { sources to fully } \\
\text { achieve a specific } \\
\text { purpose, with clarity } \\
\text { and depth. }\end{array}$ & $\begin{array}{l}\text { Communicates, } \\
\text { organizes and } \\
\text { synthesizes } \\
\text { information from } \\
\text { sources. Intended } \\
\text { purpose is achieved. }\end{array}$ & $\begin{array}{l}\text { Communicates and } \\
\text { organizes } \\
\text { information from } \\
\text { sources. The } \\
\text { information is NOT } \\
\text { yet synthesized, so } \\
\text { the intended } \\
\text { purpose is NOT } \\
\text { fully achieved. }\end{array}$ & $\begin{array}{l}\text { Communicates } \\
\text { information from } \\
\text { sources. The } \\
\text { information is } \\
\text { fragmented and/or } \\
\text { used inappropriately } \\
\text { (misquoted, taken } \\
\text { out of context, or } \\
\text { incorrectly } \\
\text { paraphrased, etc.), } \\
\text { so the intended } \\
\text { purpose is NOT } \\
\text { achieved. }\end{array}$ & $\begin{array}{l}\text { Does NOT } \\
\text { communicates } \\
\text { information from } \\
\text { sources. }\end{array}$ \\
\hline
\end{tabular}

